\title{
HOW LOCAL POPULATION PERCEIVE IMPACT OF BROWNFIELDS ON THE RESIDENTIAL PROPERTY VALUES: SOME REMARKS FROM POST-INDUSTRIAL AREAS IN THE CZECH REPUBLIC
}

\author{
Kamila TURECKOVA ${ }^{1}$, Stanislav MARTINAT ${ }^{1}$, Jaroslav SKRABAL ${ }^{1}$, \\ Petra CHMIELOVA ${ }^{1}$, Jan NEVIMA ${ }^{1}$
}

DOI: $10.21163 / G T \_2017.122 .13$

\begin{abstract}
:
Brownfields are an integral part of contemporary cities in Central Europe. It is obvious that the occurrence of brownfields influences the value of residential properties that are located in their neighbourhoods. In our research, we focused on the problem of perception of brownfields and ways how the perception of these sites affects prices of local real estate. Set of questionnaire surveys was conducted in three case study municipalities (Karvina, Orlova, Detmarovice in the Czech Republic) to ascertain factors that cause the specific perception of brownfields in municipalities that are heavily affected by the heavy industry and mining. It was found that brownfields are perceived quite negatively here and local population believes that the occurrence of brownfields significantly affects local residential property values. More polarized opinions of the population have been ascertained in case of Karvina, where plenty of brownfields are located within the settled part of the city. A key finding of our survey is that spatial distribution of brownfields within the particular city is of crucial importance while thinking about the impact of brownfields on the residential property values.
\end{abstract}

Key-words: Brownfield regeneration, Residential property values, Post-industrialism, Perception of brownfields.

\section{INTRODUCTION}

Nowadays when plenty of global economic, social and environmental challenges that are linked to the sustainable spatial development of cities and municipalities are being solved (Brown, 2012), the problem of regeneration and re-use of brownfields might at least partially contribute to the solution of these issues (Nijkamp et al., 2002 or Krzysztofik et al., 2016). One of those problems is to reduce the undesirable increase of extent of built-up areas beyond city limits on the account of the open landscape in times when brownfields in inner cities are being abandoned and left unused (Frantal et al., 2015). Indeed, boosting support for brownfield regeneration might contribute to more sustainable development of cities and rural municipalities from the perspective of their physical compactness (Ganser \& Williams, 2012), might reduce consequent environmental and health risks for local population (Litt et al., 2002, Eiser et al., 2007) or tourists (Alker \& Stone, 2005) and significantly contribute to an increase of attractiveness of cities and municipalities (Andrés and Grésillon, 2013 or Berkes, 2017). Such support might also help to enhance our responsibility (Tagaia, 2016) for implications of our industrial history that is still

\footnotetext{
${ }^{1}$ School of Business Administration in Karvina, Silesian University in Opava, 73340 Karvina, Czech Republic, tureckova@opf.slu.cz, martinat@opf.slu.cz, skrabal@opf.slu.cz, chmielova@opf.slu.cz, nevima@opf.slu.cz.
} 
significantly affecting face and structure of our contemporary cities (Pacione, 2009). Generally, support for brownfields regeneration might strengthen our nowadays more environmentally friendly path of thinking about urban space that prefers utilization of existing properties over those that are being built on greenfields (De Sousa, 2003).

The objective of this paper is to address the problem of changing values of residential properties as one of the problems that are connected to the occurrence of brownfields in cities. We are looking on this issue from the perspective of perception of the local population. As perception of the values of residential properties significantly contribute to determination of price for which real estate are offered (e.g. Bowes \& Ihlanfeldt, 2001), we believe that our research might reveal some insights into ways how perception of brownfields is constructed by local population and which characteristics of brownfields influence values of residential properties the most. Our hypothesis is that the changing proximity of non-regenerated brownfields to residential properties influences their perceived value. The aim of the paper is to examine the influence of brownfields on the residential property values that are located in their neighbourhoods, as perceived by the local population.

It can be assumed that proximity of neglected, abandoned and decaying grounds impacts values of residential properties. Reasons behind this hypothesis lie for example in the lower level of aesthetic quality that is usually connected to such abandoned or neglected brownfields. Next reason could be linked to possible contamination of these sites, their bad technical state or occurrence and concentration of socio-pathological phenomena in these buildings (like homelessness, high level of criminality etc.). Our findings are based on the set of the surveys that have been conducted in the area of three municipalities in the Moravian-Silesian Region (Czech Republic) in 2016 and 2017. Specifically, we worked in two cities (Karvina - population 54.4 thousand in 2017, Orlova - population 29.2 in 2017) and one rural municipality (Detmarovice - population 4.2 in 2017). All three selected municipalities are located within the Ostrava agglomeration that is typical by the huge occurrence of brownfields after heavy industry and mining.

\section{THEORETICAL FRAMEWORK OF THE STUDY}

The National Brownfield Regeneration Strategy of the Czech Republic (2008) or previously Alker (2000) or Yount (2003) define brownfield as the real estate property (land, building or ground) that is insufficiently utilized, neglected and might be also contaminated. These properties occur as remnants of industrial, agricultural, residential, military or other activities on the area of cities, towns and municipalities. As has been proved by many studies, the occurrence of brownfields significantly affects values of residential properties that are located in neighbourhoods of these sites (e.g. De Sousa, 2000, Kaufman \& Clautier, 2006, Mihaescu \& vom Hofe, 2012, Sun \& Jones, 2013). It is also well known that the property prices are constructed by characteristics of the local real estate market where geographical location belongs to factors of crucial importance (e.g. Can, 1992 or Hesse, 2004). Undoubtedly, values of residential properties in the neighbourhood of brownfields are also considerably influenced by the way how population perceive these sites (Munroe, 2007). Willingness to purchase the real estate in the proximity of brownfield is affected by the mix of factors (Boyd et al., 1996), part of them might be described as "hard" factors (like already mentioned geographical location, accessibility of the site, availability of infrastructure) and part of them as "soft" factors where perception surely belongs. These soft factors are usually not of static, but more of dynamic nature that might 
be changed due to course of time as the process of particular brownfield regeneration approaches. On the contrary, once brownfield regeneration process is finished, values of residential properties in neighbourhoods usually increase.

Spatial distribution of demand for real estate within cities is strongly uneven (Rodrigues et al., 2001). Indeed, such unevenness is a natural part of relations in market economy, however, in case of cities where plenty of non-regenerated brownfields could be found, variations in residential property values could be shown differently (Robert \& Kimberly, 2005. As it is displayed in Figure 1, the occurrence of brownfields causes a decrease of property residential values no matter in which urban zone (city centre, inner city, suburban zone) they are located. Although this distribution of bid-rent curve in Figure $\mathbf{1}$ is of quite hypothetical nature, we can clearly see the increase of the curve with growing distance from particular brownfield. In reality, the line of the curve in the proximity of brownfields is definitely not so simple and might vary according to the local conditions. Moreover, not all brownfields are the same, some of them are partly utilized, only part of them is "no-man's land" (McCan, 2013) where people do not live. This assumption makes a line of the curve even more complicated. To sum-up, areas in the neighbourhood of brownfields are over shaped by many other external relations and every single site is a unique space with unique socio-cultural background and is anchored by various spatial relations. It is a challenge for contemporary urban planning to deal with the issue of brownfields (Maly \& Mulicek, 2016 or Klusacek et al., 2011) that such significantly affects the structure of contemporary cities. Perception of brownfields has been studied by Greenberg et al. (1995), Rizzo et al. (2015), Martinat et al. (2016), alternative re-use options have been widely discussed by e.g. Rall \& Haase (2011) or Stasakova \& Kulla (2016). Implications about the place-making of urban space by its re-use by urban farming has have been widely discussed by Koopmans et al. (2017), consequences for rural space are examined by Navratil et al. (2016).

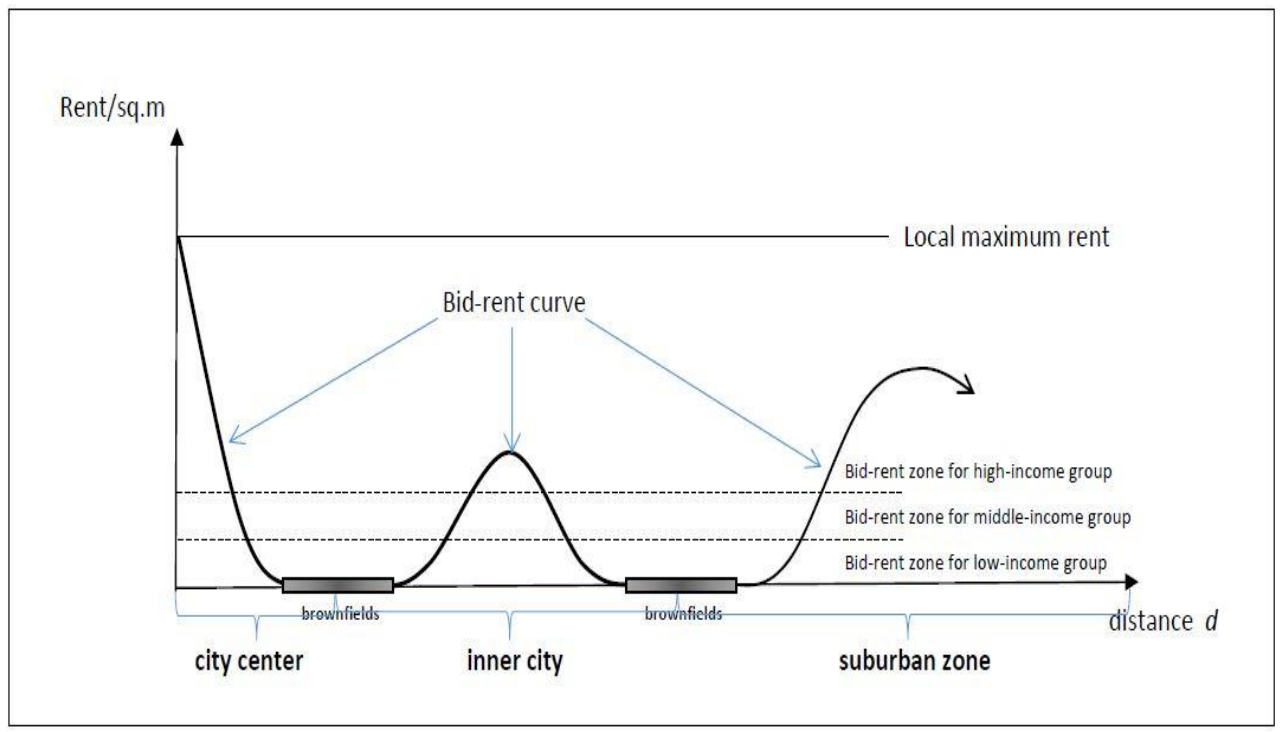

Fig.1 Hypothetical effects of brownfields on bid-rent curve in urban space. Sources: Authors processing (based on McCan, 2013, p. 128). 


\section{METHODOLOGY AND DATA}

As a first step of the presented research, a detailed literature retrieval was performed to understand the problem, nature and specifics of the regeneration of brownfields in heavy industrialized regions that used to serve as crucial base for the national economy for decades but recently they are losing their position as post-industrial tendencies in society are approaching and importance of industrial production is decreasing. A study of this phenomenon assumes a utilisation of transdisciplinary approaches, as the usage of limited methodologies of individual disciplines might deform the meaningful perspective of the results interpretation. According to the knowledge of authors, it is not possible to perceive the multilayer problem of brownfields just from the economic, sociological or geographical point of view, it is necessary to combine these perspectives to get better results.

Individual phases of conducted research were performed simultaneously in two cities (Karvina, Orlova) and one rural municipality (Detmarovice) of the Moravian-Silesian Region in 2016 and 2017. Firstly, these three municipalities were selected due to the strong occurrence of brownfields as the result of the restructuring of their economy in the last two decades. On the basis of open access brownfields inventories, a database for the three municipalities was developed. Relevancy of data was verified by means of the field research in winter months of 2016. Secondly, the data on perception of residential property values were gathered by means of the questionnaire survey. The questionnaire has been created on the basis of previous studies and contained 12 questions. A preliminary survey was conducted in March 2016 to be sure that individual questions are clearly defined and to avoid any misinterpretations. Individual questionnaires were gathered by trained university students by a face-to-face communication with respondents on the streets of the three municipalities. The questionnaires were completed by the method of semi-structured interviews. A number of respondents that participated in the research were 347 in total (158 respondents from Karvina, 120 respondents from Orlova, 69 respondents from Detmarovice). A number of respondents, who participated in the survey, was ensured to be at least 3\% of the total population of individual municipalities. All respondents were selected to match with socioeconomic, demographic, educational and gender structure of the population of given municipalities. All respondents were older than 18 years and were selected as persons who are living, working or studying on the area of the three municipalities (Tab. 1). Respondents were selected to be sure that all parts of municipalities, where brownfields are located, are represented. The share of returned questionnaires was high (around $90 \%$ ) due to face-to-face communication with respondents which minimized the level of refusals to participate in the survey. The aim of the questionnaire survey was to ascertain opinions and attitudes of the local population on the issue of the influence of brownfields on prices of the neighbouring real estate. Factors behind were also determined to ensure why and how the occurrence of brownfields affects the value of local residential properties.

\section{DESCRIPTION OF THE SELECTED LOCATIONS}

Karvina, Orlova and Detmarovice are municipalities on the LAU 2 level that are located in the Czech Republic in the eastern part of the Moravian-Silesian Region (on the area of former Karvina District -LAU 1) by the borders with Poland (Fig. 2). All three Silesian municipalities are neighbours and are located in the eastern part of the Ostrava agglomeration that is typical by heavy industrialisation that has been taking part here since the middle of the $19^{\text {th }}$ century. 
Segmentation of respondents of surveys in three municipalities

Table 1

\begin{tabular}{|c|c|c|c|c|}
\hline & & Karvina & Orlova & Detmarovice \\
\hline & $\begin{array}{ll}\text { Number } & \text { of } \\
\text { questionnaires }\end{array}$ & 158 & 120 & 69 \\
\hline Gender & $\begin{array}{l}\text { Female } \\
\text { Male }\end{array}$ & $\begin{array}{l}49.4 \% \\
50.6 \%\end{array}$ & $\begin{array}{l}61.9 \% \\
38.1 \%\end{array}$ & $\begin{array}{l}59.8 \% \\
40.2 \%\end{array}$ \\
\hline Age & $\begin{array}{l}18-25 \text { years } \\
26-35 \text { years } \\
36-45 \text { years } \\
46-55 \text { years } \\
56-65 \text { years } \\
65 \text { and more years }\end{array}$ & $\begin{array}{l}6.3 \% \\
13.9 \% \\
19 \% \\
24.1 \% \\
21.5 \% \\
15.2 \%\end{array}$ & $\begin{array}{l}13 \% \\
23.2 \% \\
27.8 \% \\
14.6 \% \\
15.4 \% \\
6 \%\end{array}$ & $\begin{array}{l}22 \% \\
22.8 \% \\
24.9 \% \\
18.1 \% \\
5.9 \% \\
6.1 \%\end{array}$ \\
\hline Education & $\begin{array}{l}\text { Elementary } \\
\text { Secondary without } \\
\text { final exam } \\
\text { Secondary with } \\
\text { final exam } \\
\text { Tertiary }\end{array}$ & $\begin{array}{l}4.4 \% \\
24.1 \% \\
56.3 \% \\
15.2 \%\end{array}$ & $\begin{array}{l}6.9 \% \\
47.1 \% \\
16.3 \% \\
29.7 \%\end{array}$ & $\begin{array}{l}7.2 \% \\
22.8 \% \\
52.6 \% \\
17.4 \%\end{array}$ \\
\hline Social status & $\begin{array}{l}\text { Students } \\
\text { Employees } \\
\text { Entrepreneurs } \\
\text { Unemployed } \\
\text { Retired persons } \\
\text { Persons on } \\
\text { maternal/parental } \\
\text { leave }\end{array}$ & $\begin{array}{l}8.9 \% \\
60.1 \% \\
12 \% \\
2.5 \% \\
12 \% \\
4.4 \%\end{array}$ & $\begin{array}{l}8.1 \% \\
52.9 \% \\
5.3 \% \\
8.7 \% \\
17.7 \% \\
7.3 \%\end{array}$ & $\begin{array}{l}13 \% \\
59.1 \% \\
10.5 \% \\
1.5 \% \\
9.6 \% \\
6.4 \%\end{array}$ \\
\hline $\begin{array}{l}\text { I live not more } \\
\text { than } 500 \text { meters } \\
\text { from } \\
\text { brownfield }\end{array}$ & $\begin{array}{l}\text { Yes } \\
\text { No }\end{array}$ & $\begin{array}{l}78 \% \\
22 \%\end{array}$ & $\begin{array}{l}89 \% \\
11 \%\end{array}$ & $\begin{array}{l}30 \% \\
70 \%\end{array}$ \\
\hline
\end{tabular}

Source: set of own surveys $(n=347)$

All three selected municipalities are typical by the occurrence of brownfields as a consequence of recent economic development and post-industrial tendencies in society. While Karvina and Orlova are cities where prefabricated houses that were built during the Communist era for miners and workers in heavy industry prevail, Detmarovice could be characterized more as the large industrial village where agricultural activities are also operated to a certain extent. Karvina is the largest municipality as for its population (54.4 thousand in 2017) and covers area of $57.5 \mathrm{~km}^{2}$. Discovery of black coal in Karvina in the second half of the $19^{\text {th }}$ century caused a decisive turn in the economic development of the wider region. The mining sector has been gradually complemented by engineering and metallurgy that constituted the backbone of the traditional economy of the region. After the fall of the Iron Curtain, heavy industry and mining have been scaled down. However, black coal is still mined until today (around nine thousand employees work in mines), but the mines should be closed in the middle of 2020s. Karvina is also known as the location of spa that utilized local rich sources iodobromic groundwater. Orlova is typical by mining and heavy industry whose tradition also goes back to early $19^{\text {th }}$ century. Orlova (population 29.2 thousand) covers an area of $24.7 \mathrm{~km}^{2}$ and might be characterized by mildly sloping 
terrain that was accented by visible surface effects of mining. Plenty of people of Karvina and Orlova whose population number is dramatically declining (by one-third in the last two decades) are daily commuting to work in the nearest region centre, Ostrava (population 291.6 thousand in 2017), but high local unemployment rate (10\% in Orlova, $12 \%$ in Karvina in 2017) and consequent social problems are still problematic. Both mentioned cities are facing problems and challenges that are connected to the processes of urban shrinkage. Detmarovice (population 4.2 thousand on the area of $13.8 \mathrm{~km}^{2}$ ) is located north of Orlova on important railway track from Bohumin to Slovakia (Zilina) and Poland (Katowice). On the area of Detmarovice, electrical power station with an installed capacity of $800 \mathrm{MW}$.

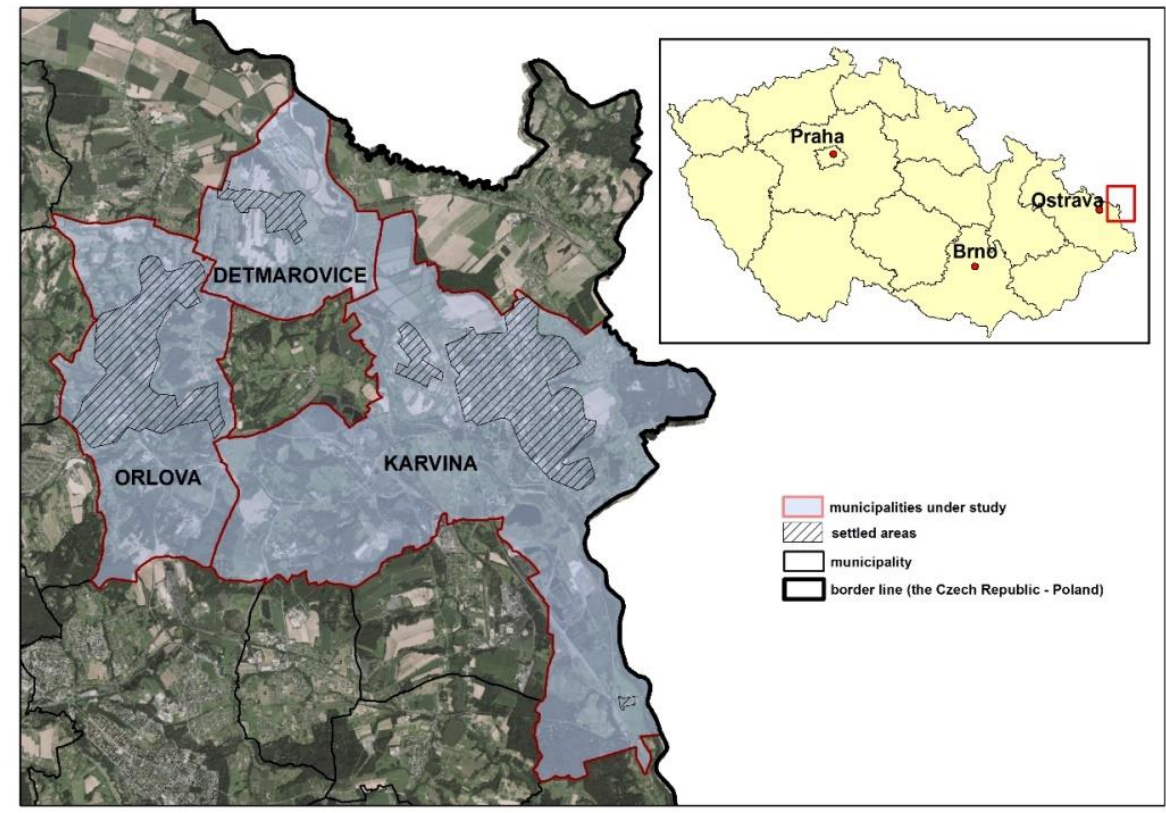

Fig. 2 Location of the three case study municipalities.

Source: Authors processing.

Within the three case study municipalities, eighteen brownfields are located in Karvina, eight on the area of Orlova and eleven on the area of Detmarovice. Structure of brownfields as for their size and origin differs in individual municipalities, however, the majority of local brownfields are connected to mining and heavy industry. In case of Detmarovice, housing is typical original use for local brownfields.

Majority of brownfields in Karvina are located in close proximity to areas with housing function (see Figure 3a). From this perspective, exceptional are brownfields in the eastern part of the city (five brownfields) that are connected to mining and are located out of settled areas (Sovinec, former Gabriela mine, former Jindrich mine, former Barbora mine, area Above Barbora). Next examples of brownfields in Karvina are former panel factory, former gardening, former school, water tower, the Larisch stables, abandoned houses on the main square or former housing with name Vagonka. The total area of brownfields in Karvina is over 180 hectares. However, it has to be stated that majority of the large-scale post-mining 
landscape in the eastern part of Karvina, where surface effects of mining are visible and are not included in calculations as they are difficult for delimitation. Thus, the real extent of brownfields in Karvina is much higher.

Majority of brownfields in Orlova are also linked to the recent decay of mining that has been taking place here gradually since the middle of the 1990s. Some brownfields have already been re-naturalised (technical and biological re-naturalisation has been already done here), other brownfields are still waiting for such intervention. The total area of brownfields in Orlova is around 5,000 hectares (buildings and lands of former Lazy mine, Vaclav mine (engine buildings, administration buildings), Doubrava mine, Zofie mine, a heap of Zofie mine, the area of Floating pit no. 2, neglected pool or former aquapark. As can be seen in Figure 3b, in Orlova, the majority of brownfields are located out of settled parts of the city. In case of Orlova post-mining landscape has been included to list of brownfields since official delimitation has been conducted by local administration. This is the reason why acreage of brownfields in Orlova is much higher than in Karvina (both numbers are incomparable).

In Detmarovice, the majority of brownfields are located in the proximity to the main railway station or in the proximity of the power station (abandoned storages - please see Figure 3c). Besides it, three buildings of former civic facilities, four abandoned buildings after industry, one abandoned agricultural farm and three neglected houses. The total area is very small, just around 0.5 hectares. Brownfields after mining are not located on the area of Detmarovice.

\section{RESULTS}

\section{Perception of the influence of brownfields on the residential property values}

During our surveys, it was ascertained as a key finding that living in the neighbourhood of brownfields is problematic for the majority of respondents (see Figure 4).This is quite surprising finding as the occurrence of brownfields on the area of the three studied municipalities is quite frequent and it could be assumed that local population is more used to live in the neighbourhoods of these sites. The highest rate was measured in case of Karvina ( $80 \%$ ) while in two other municipalities it was slightly less. This result and differences among individual municipalities can be explained rather a consequence of negative phenomena that are usually connected to the occurrence of brownfields (criminality, homelessness etc.). Extreme values in case of Karvina might be interpreted as a result of the stronger occurrence of previously mentioned phenomena and geographical location of brownfields in this city where part of them is clustered more in the settled areas while in case of Orlova and Detmarovice brownfields are more dispersed on the edges of the settlements.

Much more impressive differences in opinions of respondents were found in a question, how the local residential property values are affected by the occurrence of brownfields? The most polarized opinions were ascertained in Karvina. In this case, $44 \%$ of respondents stated that due to the occurrence of brownfields the residential property values are lower by $50 \%$ in comparison to other parts of the city without brownfields (see Figure 5). It seems that in Karvina local population is quite negative when thinking about effects of occurrence of brownfields. If we took all three cases as one whole, the most frequented answer was that brownfields decrease the value of residential properties in their neighbourhoods just by approximately $20-40 \%$. 

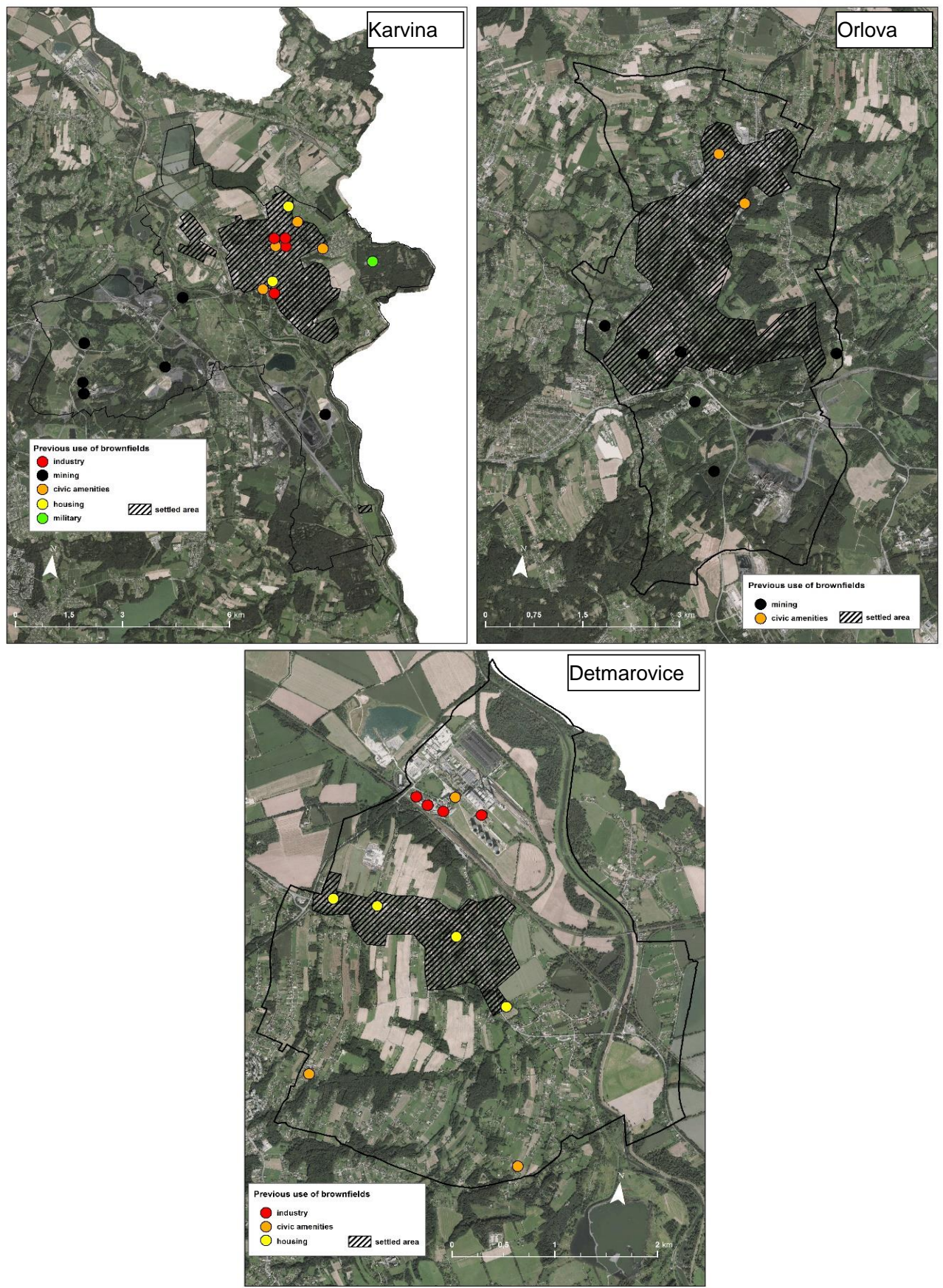

Fig. 3 (a, b, c) Spatial distribution of brownfields and indication of their original use in Karvina (a), Orlova (b) and Detmarovice (c). Source: Authors processing. 
On the other hand, almost one-fifth of respondents from Detmarovice and Orlova thinks that there is not the explicit influence of brownfields on the residential property values (in case of Karvina it was the opinion of just 2 persons that means $1 \%$ of respondents).

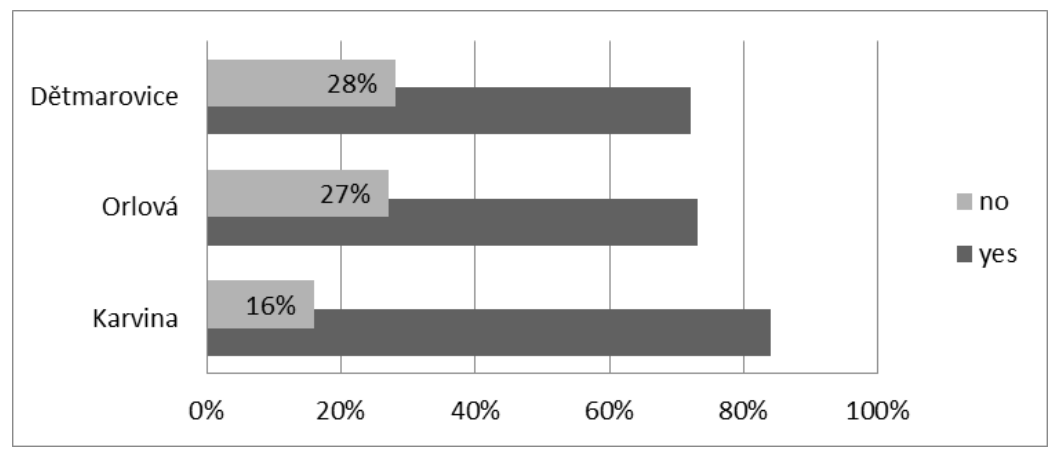

Fig. 4 Unwillingness to live in the neighbourhood of brownfields.

Source: own survey $(n=357)$.

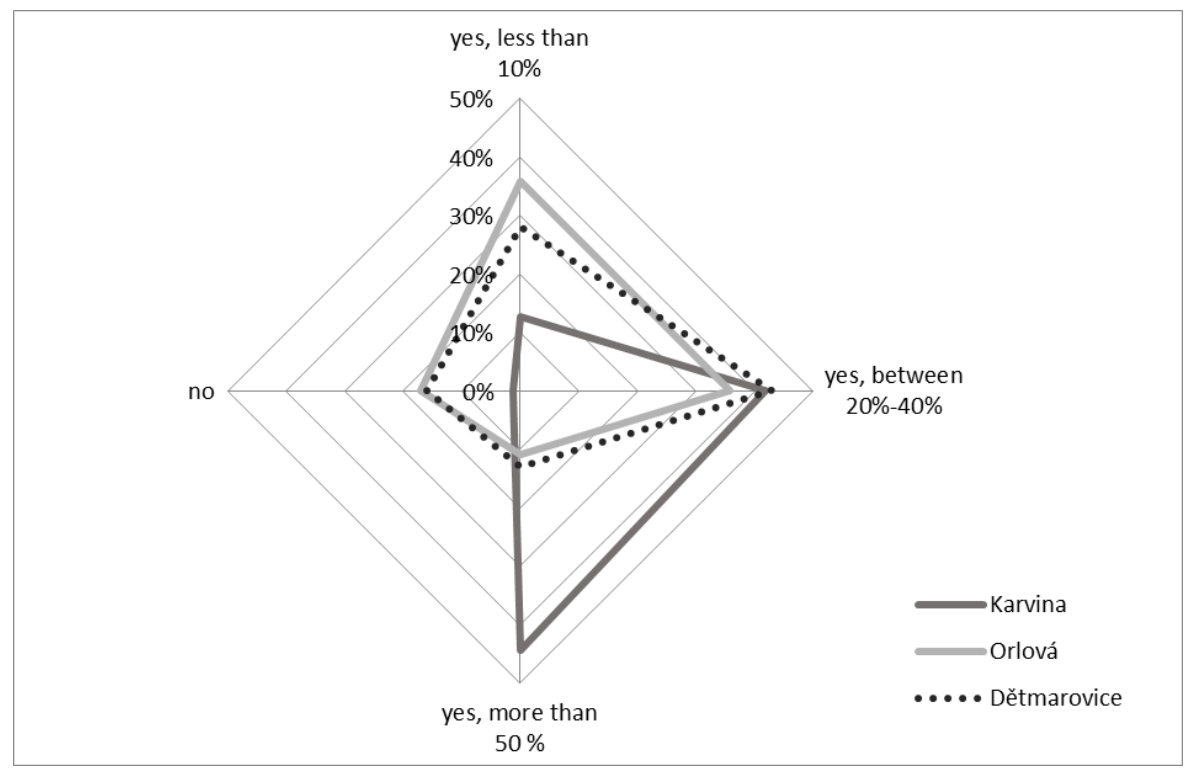

Fig. 5 Influence of brownfields on residential property values in Karvina, Orlova and Detmarovice. Source: own survey $(n=347)$.

Reasons behind this difference might be explained by using results of the survey concerning the willingness to buy residential property in the neighbourhoods of brownfield if the price is lower than $20 \%$ (results are presented in Figures 6 and 7). It seems that our hypothesis related to the specific perception of brownfields in Karvina is confirmed as the population of Karvina again evaluates this problem again differently (with much higher polarity) in comparison to other two cases. We assume that this might be caused by the dense occurrence of brownfields in Karvina and significant everyday experiences of the 
local population with life with brownfields and consequent occurrence of socially problematic phenomena.

But let's move back to the results of the surveys. We asked respondents to evaluate their willingness to buy the residential property in immediate proximity of brownfield if the price is lower by $20 \%$. This enquiry had significantly negative replies among respondents from Karvina. Only $9 \%$ of them were open to buy such residential property (see Figure 6). On the other hand, respondents from Orlova were not so negative in their answers and more than $40 \%$ of them would be opened to buy such real estate without any problems.

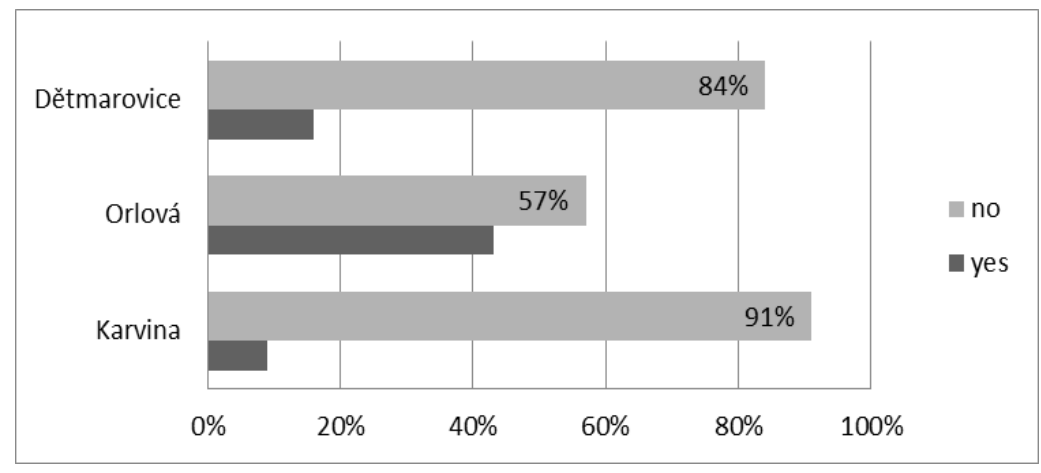

Fig. 6 Willingness to buy residential property in immediate proximity of brownfield if price is lower by $20 \%$. Source: own survey $(n=347)$.

In the next step of our research, we tried to determine factors that affect opinions of respondents that brownfields significantly affect the value of residential properties in their neighbourhoods. Respondents could select out of six defined answers. Shares of positive and negative answers are graphically displayed in Figure 7. Generally, it was found that population of Karvina connects occurrence of brownfields much more strongly to negative consequences (like homelessness, criminality, possible contamination and health risks for population etc.) than it is in the case of the population of Orlova or Detmarovice.

Our hypothesis that population of Karvina perceives brownfields differently (as also showed in the case of other questions) seems to be confirmed again. Surprisingly, usually reduced aesthetics of non-regenerated brownfields was not taken into account as a serious problem, similarly as consequences for urban planning (brownfields block development of the city, there is no certain future use of brownfields). It is also quite surprising that technical state of brownfields is also perceived as the problem of secondary importance.

The largest share of respondents (around $84 \%$ ) is convinced that brownfields as an abandoned sites are problematic and rather dangerous which is the fact that reduces prices of the neighbouring real estate. Main reasons for such argument were identified in the concentration of socially pathological phenomena in brownfields (like homelessness, higher rates of criminality, drug dealing, vandalism etc.). The second factor that was found as important (around $60 \%$ ) were environmental and health risks (occurrence contamination of soils and pollution) that might affect the health of the population that is living in the neighbourhoods. This factor might be interpreted as some kind of distrust that majority of contamination have been removed or cleaned up. The population was quite unsure that these contaminants are safe and do not bear any health risks. The technical state of brownfields was identified as a third important factor (around $56 \%$ ). 


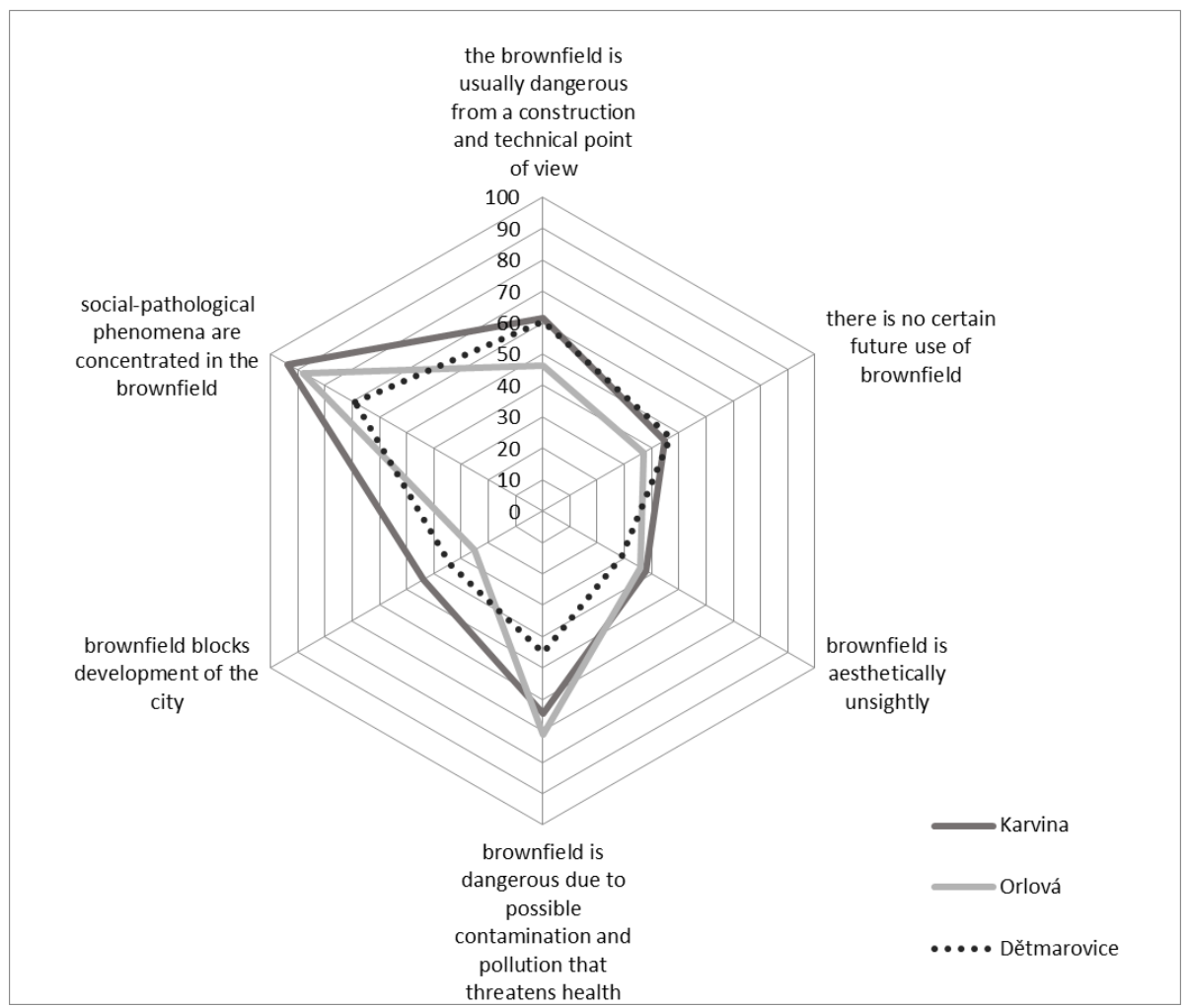

Fig. 7 Reasons why brownfields have significant influence on the residential property values. Source: own survey $(n=347)$.

Respondents were expressing their fears that brownfields are dangerous as for the bad quality of their technical infrastructure, and not usually secured against the intrusion of people who should not be there. They perceive that risks connected to bad statics and neglected maintenance of individual buildings, or failures of concrete structures due to corrosion of materials are very high. Reasons why brownfields negatively influence the price of the neighbouring real estate are for $43 \%$ of respondents connected to uncertainty concerning future use of the site. They usually argued that it is not sure what will be built on a particular brownfield in future and how the site will be used. Only $34 \%$ of respondents perceived brownfields as barriers for the further development of the city. We can say respondents were not so optimistic when thinking about the future development of their city. It seems that this distrust towards future reduces demand for housing within the city and indirectly it noticeably reduces the value of the local real estate. The same share of respondents $(34 \%)$ believes that lower real estate prices of buildings in proximity to brownfields are connected to aesthetics of brownfields. These sites are usually abandoned and neglected, sometimes aesthetically unsightly with peeled façade or are ruined, covered by weed or walls are damaged by graffiti etc. As the final question of our survey, respondents were asked to evaluate the possibility to buy the real estate in the proximity of brownfields. Just $17 \%$ of them claimed that occurrence of brownfields does not influence their decision to buy real estate, $9 \%$ of them expressed their opinion even stronger (absolutely no influence). 


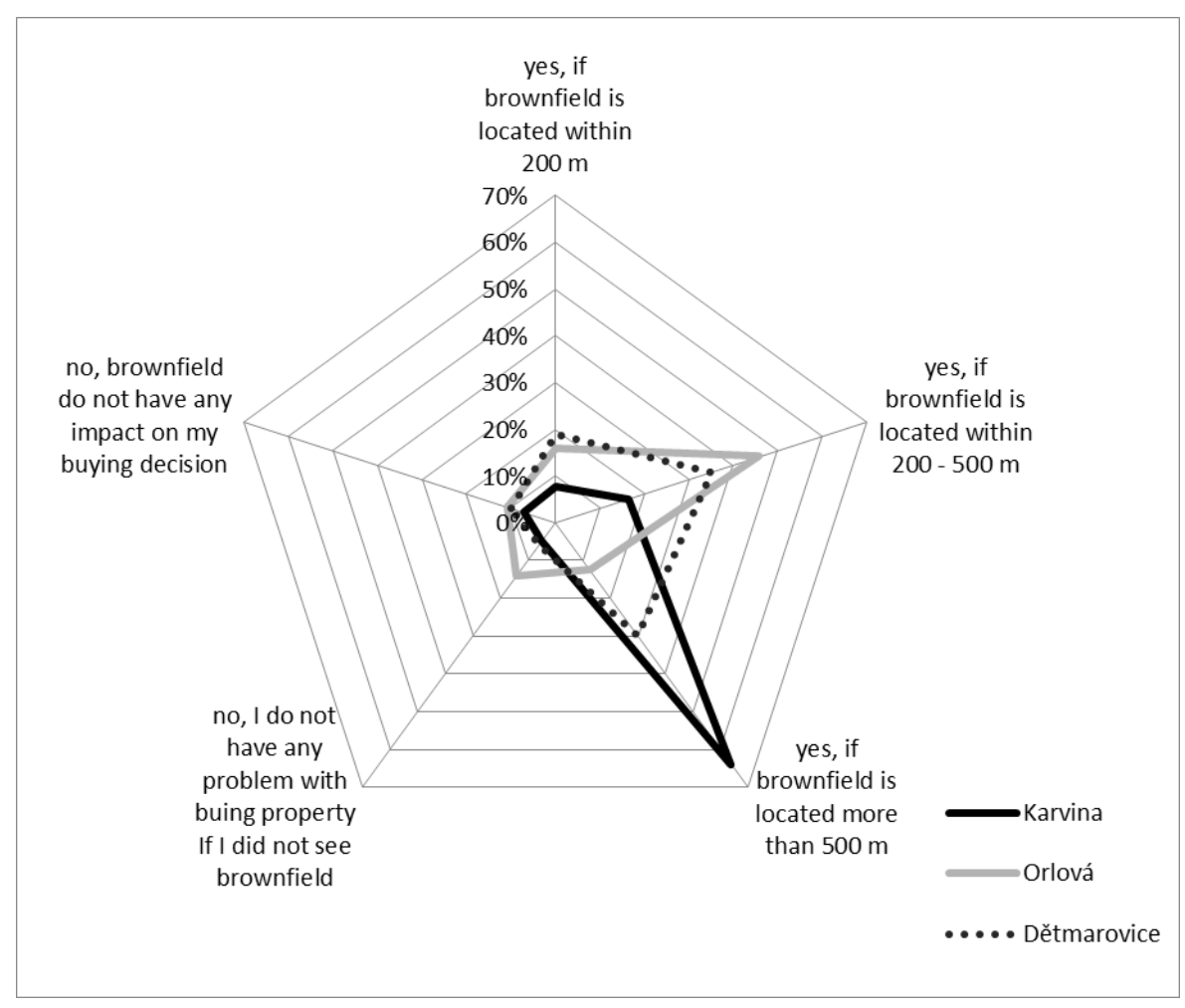

Fig. 8 Influence of brownfields on real estate buying behaviour of respondents.

Source: own survey $(n=357)$.

On the other hand, as might be clearly seen in Figure 8, the population of Karvina strongly refuse to buy real estate in the proximity of brownfields $(64 \%)$. This result is quite surprising due to the fact that majority of the population of Karvina lives in proximity of brownfields, but it is in line with previous replies of respondents from Karvina, who really seem to perceive brownfields differently and more with negative connotations. Respondents from Karvina argue that they would buy the real estate only of its location was in larger distance than 500 meters from brownfield which is hardly realistic in this city. It can be also stressed that the respondents in Orlova were not so strict and admit that they are willing to buy the real estate in the proximity of brownfields.

\section{DISCUSSION AND CONCLUSION}

The occurrence of brownfields is usually perceived as a weakness or a threat for future development of cities, towns and municipalities. On the other, brownfields might also be considered as an opportunity for development (Adams et al., 2010). These sites are usually unsightly and aesthetically do not meet requirements of the local population how the city should look like which significantly affect the perception of these sites (Martinat et al., 2017). The problem of brownfields is especially distinct in cities that are heavily affected by the recent decay of the heavy industry and mining, where it might be assumed that brownfields are specifically perceived (Krzysztofik et al., 2012). Systematic regeneration of 
brownfields might undoubtedly contribute to the improvement of the quality of life in these cities (Pediaditi et al., 2010) and at least partially contribute to a more environmentally friendlier way of thinking of nowadays society (Apsan, 2002).

The aim of the paper was to examine the perception of brownfields on the values of residential properties, as perceived by the local population. The set of semi-structured interviews has been conducted in three municipalities (Karvina, Orlova, Detmarovice) that are significantly affected by the occurrence of brownfields. By means of our survey hypothesis was confirmed that the occurrence of brownfields significantly affects the value of the residential properties. Brownfields are perceived quite negatively as the local population believes that they reduce prices of residential properties. This finding is in line with the results of previous studies (e.g. Bond et al., 2004). Respondents of our survey also claimed in their majority that they would not buy the real estate in the proximity of brownfield even if the price was reduced by on fifth in comparison with other locations within the same city or municipality. Such exact finding can be hardly generalized, however, the stand-off of local population from purchasing the real estate in the neighbourhoods of non-regenerated brownfield seems to be clear. This argument might utilized while arguing for the speeding-up of the brownfield regeneration process.

Factors that the most significantly influence such decision is a concentration of socially pathological phenomena and risks connected to possible contamination of brownfields and health risks for the local population. If we focus on results in individual municipalities, it was ascertained that population of Karvina perceive brownfields the most negatively than the population of Orlova or Detmarovice. The reason behind this difference in perception of brownfields might be identified in the spatial distribution of brownfields in Karvina where these sites might be found practically everywhere while in other two municipalities, the locations of brownfields are different (primarily on the edge of municipalities). In Karvina, majority of the population lives their everyday lives in close contact with brownfields and negative phenomena that are connected to brownfields (homelessness, a higher level of criminality, vandalism etc.) significantly affect their opinions about brownfields.

\section{ACKNOWLEDGMENT}

This paper was kindly supported by the project with the title; Brownfields in urban and rural space: geographic, economic, historical, legal contexts and their importance for regional development (BURAN) (SGS/21/2016).

\section{R E F E R E N C E S}

Adams, D., De Sousa, C., \& Tiesdell, S. (2010) Brownfield development: A comparison of North American and British approaches. Urban Studies, 47 (1), 75-104.

Alker, S., Joy, V., Roberts, P., \&Smith, N. (2000). The definition of brownfield. Journal of Environmental Planning and Management, 43 (1), 49-69.

Alker, S., \& Stone, C. (2005) Tourism and leisure development on brownfield sites: an opportunity to enhance urban sustainability. Tourism and Hospitality Planning \& Development, 2 (1), 27-38.

Apsan, H. N. (2002) Environmental Value: A Business View of Environmental Costs and Opportunities. Environmental Quality Management, 11 (4), 75-81.

Andres, L. \& Grésillon, B. (2013) Cultural brownfields in European cities: a new mainstream object for cultural and urban policies. International Journal of Cultural Policy, 19 (1), 40-62.

Berkes, J. (2016) I like living here. Social stratas attachment to the Hungarian big cities. DETUROPE - Journal of Regional Development and Tourism, 8 (2), 8-22. 
Bond, S., \& Cook, D. (2004) Residents' Perceptions Towards Asbestos Contamination of Land and It's Impact on Residential Property Values. Pacific Rim Property Research Journal, 10 (3), 328352.

Boyd, J., Harrington, W., \& Macauley, M. K. (1996) The effects of environmental liability on industrial real estate development. The Journal of Real Estate Finance and Economics, 12 (1), 37-58.

Bowes, D. R., \& Ihlanfeldt, K. R. (2001) Identifying the impacts of rail transit stations on residential property values. Journal of Urban Economics, 50 (1), 1-25.

Brown, L. (2012) World on the edge: how to prevent environmental and economic collapse. New York: Routledge.

Can, A. (1992) Specification and estimation of hedonic housing price models. Regional Science and Urban Economics, 22 (3), 453-474.

De Sousa, C. A. (2000) Brownfield redevelopment versus greenfield development: A private sector perspective on the costs and risks associated with brownfield redevelopment in the Greater Toronto Area. Journal of Environmental Planning and Management, 43 (6), 831-853.

De Sousa, C. A. (2003) Turning brownfields into green space in the City of Toronto. Landscape and urban planning, 62 (4), 181-198.

Eiser, J. R., Stafford, T., Henneberry, J., \& Catney, P. (2007) Risk perception and trust in the context of urban brownfields. Environmental Hazards, 7 (2), 150-156.

Frantal, B., Greer-Wootten, B., Klusacek, P., Krejci, T., Kunc, J., \& Martinat, S. (2015) Exploring spatial patterns of urban brownfields regeneration: The case of Brno, Czech Republic. Cities, 44, 9-18.

Ganser, R., \& Williams, K. (2007) Brownfield development: Are we using the right targets? Evidence from England and Germany. European Planning Studies, 15 (5), 603-622.

Greenberg, M., Schneider, D., \& Parry, J. (1995) Brown fields, a regional incinerator and resident perception of neighborhood quality. Risk, 6, 241-259.

Hesse, M. (2004) Land for logistics: locational dynamics, real estate markets and political regulation of regional distribution complexes. Tijdschrift voor Economische en Sociale Geografie, 95 (2), 162-173.

Kaufman, D. A., \& Cloutier, N. R. (2006) The impact of small brownfields and greenspaces on residential property values. The Journal of Real Estate Finance and Economics, 33 (1), 19-30.

Klusacek, P., Krejci T., Kunc, J., Martinat, S., Novakova, E. (2011): Post-Industrial Landscape in the Relation to Local Self-Government in the Czech Republic. Moravian Geographical Reports, 19(4) 18-28.

Koopmans, M.E., Keech, D., Sovova, L., \& Reed, M. (2017). Urban agriculture and place-making: Narratives about place and space in Ghent, Brno and Bristol. Moravian Geographical Reports, 25 (3), 154-165.

Krzysztofik, R., Runge, J., \& Kantor-Pietraga, I. (2012) Paths of Environmental and Economic Reclamation: the Case of Post-Mining Brownfields. Polish Journal of Environmental Studies, 21 (1), 219-223.

Krzysztofik, R., Tkocz, M., Sporna, T., \& Kantor-Pietraga, I. (2016) Some dilemmas of postindustrialism in a region of traditional industry: The case of the Katowice conurbation, Poland. Moravian Geographical Reports, 24 (1), $42-54$.

Litt, J. S., Tran, N. L., \& Burke, T. A. (2002) Examining urban brownfields through the public health "macroscope". Environmental Health Perspectives, 110 (Suppl 2), 183-193.

Maly, J., \& Mulicek, O. (2016) European territorial cohesion policies: Parallels to socialist central planning? Moravian Geographical Reports, 24 (1), 14-26.

Martinat, S., Kunc, J., Klusacek, P., Krejci, T., Navratil, J., Vnenkova, J., \& Cernik, J. (2015) Spatial relations and perception of brownfields in old industrial region: case study of Svinov (Ostrava, Czech Republic). Geographia Technica, 10 (2), 66-77. 
Martinat, S., Dvorak, P., Frantal, B., Klusacek, P., Kunc, J., Navratil, J., ... \& Reed, M. (2016) Sustainable urban development in a city affected by heavy industry and mining? Case study of brownfields in Karvina, Czech Republic. Journal of Cleaner Production, 118, 78-87.

Martinat, S., Navratil, J., Picha, K., Tureckova, K., Klusacek, P. (2017) Brownfield regeneration from the perspective of residents: Place circumstances versus character of respondents. DETUROPE The Central European Journal of Regional Development and Tourism, 9 (2) in press.

Navratil, J., Kucera, T., Picha, K., White Baravalle Gilliam, V. L., \& Havliková, G. (2016) The preferences of tourists in their expectations of chateau gardens: a Central and Eastern European perspective. Journal of Tourism and Cultural Change, 14 (4), 307-322.

Nijkamp, P., Rodenburg, C. A., \& Wagtendonk, A. J. (2002) Success factors for sustainable urban brownfield development: A comparative case study approach to polluted sites. Ecological Economics, 40 (2), 235-252.

Mihaescu, O., \& vom Hofe, R. (2012) The impact of brownfields on residential property values in Cincinnati, Ohio: A spatial hedonic approach. Journal of Regional Analysis \& Policy, 42 (3), 223-236.

McCan, P. (2013) Modern Urban and Regional Economics. Oxford: Oxford University Press.

Munroe, D. K. (2007) Exploring the determinants of spatial pattern in residential land markets: amenities and disamenities in Charlotte, NC, USA. Environment and Planning B: Planning and Design, 34 (2), 336-354.

Pacione, M. (2009) Urban geography: A global perspective. New York: Routledge.

Pediaditi, K., Doick, K. J., \& Moffat, A. J. (2010) Monitoring and evaluation practice for brownfield, regeneration to greenspace initiatives: A meta-evaluation of assessment and monitoring tools. Landscape and Urban Planning, 97 (1), 22-36.

Rizzo, E., Pesce, M., Pizzol, L., Alexandrescu, F. M., Giubilato, E., Critto, A., ... \& Bartke, S. (2015) Brownfield regeneration in Europe: Identifying stakeholder perceptions, concerns, attitudes and information needs. Land Use Policy, 48, 437-453.

Rall, E. L., \& Haase, D. (2011) Creative intervention in a dynamic city: A sustainability assessment of an interim use strategy for brownfields in Leipzig, Germany. Landscape and Urban Planning, $100(3), 189-201$.

Robert, S., \& Kimberly, W. G. (2005) Determining market perceptions on contamination of residential property buyers using contingent valuation surveys. Journal of Real Estate Research, 27 (2), 193-220.

Rodriguez, A., Martinez, E., \& Guenaga, G. (2001) Uneven redevelopment: new urban policies and socio-spatial fragmentation in metropolitan Bilbao. European Urban and Regional Studies, 8 (2), 161-178.

Stasakova, G., \& Kulla, M. (2016) Sights of industrial heritage and their importance for developing tourism in Slovakia. Geographical Cassoviensis, 10 (2), 159-174.

Sun, W., \& Jones, B. (2013) Using multi-scale spatial and statistical analysis to assess the effects of brownfield redevelopment on surrounding residential property values in Milwaukee County, USA. Moravian Geographical Reports, 21 (2), 56-64.

Tagaia, G. (2016) The territorial dimension of social exclusion in East-Central Europe. DETUROPE The Journal of Regional Development and Tourism, 8 (2), 58-71.

Yount, K. R. (2003) What are brownfields? Finding a conceptual definition. Environmental Practice. 5 (01), 25-33. 